\title{
Flaxseed-Derived Peptide, IPPF, Inhibits Intestinal Cholesterol Absorption and Hepatic Cholesterol Synthesis in Caco-2 and HepG2 Cells
}

Xiaolan Bao ( $\nabla$ xlb06@163.com )

Inner Mongolia Agricultural University

yuan xingyu

Kyushu University: Kyushu Daigaku https://orcid.org/0000-0002-1096-6867

\section{Xuexin Li}

Inner Mongolia Agriculture University: Inner Mongolia Agricultural University

Xiaojing Liu

Inner Mongolia Agriculture University: Inner Mongolia Agricultural University

\section{Research}

Keywords: Flaxseed peptide, Cholesterol-lowering activity, Inhibitor, Caco-2 cells, HepG2 cells.

Posted Date: July 8th, 2021

DOI: https://doi.org/10.21203/rs.3.rs-680107/v1

License: (9) This work is licensed under a Creative Commons Attribution 4.0 International License.

Read Full License

Version of Record: A version of this preprint was published at Journal of Food Biochemistry on December 11th, 2021. See the published version at https://doi.org/10.1111/jfbc.14031. 


\section{Abstract}

Background囚Flaxseed peptide (FPs) showed serum cholesterol-lowering activity in SD rats fed a highcholesterol diet, but the cholesterol-lowering amino acid sequences and mechanism of FPs were still unclear.

Methods: FPs were separated via ultrafiltration, and the amino acid sequences of the selected fractions were determined via high-performance liquid chromatography- Electrospray lonisation - Orbitrap- Mass spectrometry (HPLC-ESI-Orbitrap MS). These peptides then were synthesized by solid-phase synthesis (SPPS). IPPF with the highest CMSR was determined to exist in flaxseed protein by specific antibodies. The effects of IPPF on intestinal cholesterol absorption and hepatic cholesterol metabolism were investigated in Caco-2 cells and HepG2 cells.

Results囚1 kDa FP 5 fraction had the highest cholesterol micelle solubility inhibition rate (CMSR) $72.39 \%$ compared with the other ultrafiltration fractions. Then Eleven peptides were identified from $\mathrm{FP}_{5}$. Ile-ProPro-Phe (IPPF), with the highest CMSR 93.47\%, was selected to research the cholesterol-lowering mechanism in Caco-2 and HepG2 cells. IPPF significantly reduces the amount of cholesterol transported in Caco2 cells and the amount of total cholesterol in HepG2 cells. IPPF significantly modulated the protein levels of NCP1L1 and ABCG5/8 in Caco2 cells and significantly reduced the mRNA levels of Srebp-2 and Hmgcrin HepG2 cells.

Conclusion: IPPF inhibits cholesterol intestinal absorption through modulating the expression of cholesterol transporters in Caco-2 cells and reduces hepatic cholesterol synthesis through inhibiting the SREBP2-regulated mevalonate (HMGCR) pathway in HepG2 cells. IPPF is a new food-derived inhibitor of intestinal cholesterol absorption and hepatic cholesterol synthesis without side effects and provides a nutritional therapy component for hypercholesterolemia.

\section{Introduction}

Cholesterol is an essential structural cell membrane component biosynthesized in all animal cells and as a precursor for the biosynthesis of steroid hormones and bile acid ${ }^{[1]}$. However, increasing levels of cholesterol in the blood (Hypercholesterolemia) lead to atherosclerosis and further results in heart attack, stroke, and kidney diareses ${ }^{[2]}$. Exogenous and endogenous cholesterol are considered as the two main sources of cholesterol in the blood ${ }^{[3]}$. Exogenous cholesterol mainly comes from dietary intake, which can be attenuated by inhibiting cholesterol intestinal absorption ${ }^{[4]}$. Endogenous cholesterol is synthesized in the liver. A pathology review reported that reducing the endogenous cholesterol levels through inhibiting the cholesterol biosynthesis could effectively reduce the risk of hypercholesterolemia and cardiovascular disease ${ }^{[5]}$. Currently, statins are the most ubiquitous medicines for lowering cholesterol levels by inhibiting cholesterol de novo synthesis in liver. However, statins have been reported having many side effects, such as intestine reaction, muscle reaction and type 2 diabetes ${ }^{[6]}$. Thus, there is a significant value using food ingredients or nutrients to reduce cholesterol levels. 
Several plant proteins and peptides have been reported to have cholesterol-lowering activity. The dietary intake of Lupinus angustifolius proteins decreases serum cholesterol and HDL-cholesterol levels by upregulating Srepb-2 and Cyp7a 1 gene expression ${ }^{[7]}$. Tartary buckwheat peptides obviously decrease hepatic cholesterol levels and increase fecal acidic sterols by inhibiting the gene expression of NPC1L1 and ACAT2 in the intestines ${ }^{[8]}$. Flaxseed (Linum usitatissimum L.), also called linseed, contains $56-70 \%$

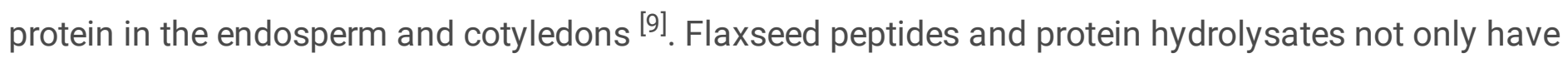
great processing characteristics but also have many physiological activities such as ACE inhibitors and anti-inflammation. Flaxseed protein hydrolysates remarkably suppresses the inflammation and oxidative stress of hepatic damage in Wistar rats ${ }^{[10]}$. Arg-rich flaxseed peptide fractions lowered the systolic blood pressure in spontaneously hypertensive rats ${ }^{[11]}$. However, few studies reported whether flaxseed peptides have cholesterol-lowering activity.

Our previous unpublished study showed that flaxseed peptide (FPs) has been proven to have cholesterollowering activity in SD rats fed a high-cholesterol diet. However, the amino acid sequences of FPs and mechanisms of FPs on regulating cholesterol metabolism are still unclear. In the present study, FPs were separated via ultrafiltration, and the amino acid sequences of the selected fractions were determined via high-performance liquid chromatography- Electrospray lonisation - Orbitrap- Mass spectrometry (HPLCESI-Orbitrap MS). These peptides then were synthesized by solid-phase synthesis (SPPS). IPPF with the highest CMSR was determined to exist in flaxseed protein by specific antibodies and selected for followup study. Subsequently, the effects of IPPF on intestinal cholesterol absorption and hepatic cholesterol metabolism were investigated in Caco-2 cells and HepG2 cells. This study provides a theoretical basis for developing a food-derived cholesterol-lowering functional ingredient to prevent hypercholesterolemia.

\section{Material And Methods}

\subsection{Materials and reagents}

Low-temperature defatted flaxseed proteins were obtained from Inner Mongolia Fengjimiao Agricultural Products Technology Development Co., Ltd. Caco-2 and HepG2 cells were purchased from the Institute of Biochemistry and Cell Biology (CAS; Shanghai, China). Protease M was obtained from Nippon Amano Enzyme Co., Ltd., Japan. The following materials were used: an AL204 electronic balance (Mettler Toledo Co., Ltd., Switzerland), an 8200 stirred ultrafiltration cell (Millipore Co., Ltd., USA), and a FreeZone ${ }^{\circledR} 4.5$ desktop freeze dryer (American Labconco Corporation, USA). Electrophoresis, a transfer tank (Bio-Rad, USA), and a MultiSkan3 microplate reader (Thermo Fisher Scientific, USA) were also utilized. Ultimate 3000 HPLC-ESI-Orbitrap MS with Protect-1FD Ultra-clean workbench (Agilent Co. Ltd, USA). $\mathrm{CO}_{2}$ incubator (Thermo Fisher Scientific, USA), and an inverted microscope (Nikon Co., Ltd., Japan). MEM basic medium, bovine albumin, and antibiotics were procured from Sigma Co., Ltd., USA. Millicell electrical resistance system (ERS) and electrical resistance meter were acquired from Thermo Fisher Scientific, USA. Anti- $\beta$ actin, NPC1L1, ABCG5/G8 (1:1000, rabbit, Abcam Inc., UK), cell lysate, Western blot kit (NJJC, Nanjing, 
China). Transcriptor First Strand cDNA Synthesis Kit (Roche, Berlin, Germany). SYBR® Premix EX Taq II Kit (Takara, Shiga, Japan). Thermal Cycler Mx3000P QPCR System (Agilent, CA, USA)

\subsection{Preparation of flaxseed protein hydrolysates}

First, $1 \mathrm{~g}$ of protein was weighed in a beaker and added with $50 \mathrm{~mL}$ of distilled water. $\mathrm{pH}$ was adjusted to 3.3 by using $1 \mathrm{~mol} / \mathrm{L} \mathrm{HCl}$. The solution was then placed on a constant-temperature magnetic stirrer and added with $0.01 \mathrm{~g}$ of protease $\mathrm{M}$ (optimum $\mathrm{pH}=3.3$, optimum temperature $=50^{\circ} \mathrm{C}, \mathrm{E} / \mathrm{S}$ ratio $=1: 100$ ) when the temperature reached $50^{\circ} \mathrm{C}{ }^{[10]}$. The temperature was maintained at $50^{\circ} \mathrm{C}$, and enzymatic hydrolysis was conducted for $1 \mathrm{~h}$. The enzyme was degraded by incubating the solution in a boiling water bath for $15 \mathrm{~min}$. The solution was cooled to room temperature and centrifuged at $1792 \mathrm{r} / \mathrm{min}$ for $20 \mathrm{~min}$. Afterward, pH was adjusted to 7 by adding $1 \mathrm{~mol} / \mathrm{L} \mathrm{NaOH}$, and then the supernatant was freeze-dried.

\subsection{Cholesterol micelle solubility inhibition rate of different FP fractions}

FPHs were separated using an ultrafiltration with molecular weight of 1, 3, 5, and $10 \mathrm{kDa}$. Five types of ultrafiltration components of $\leq 1,1-3,3-5,5-10$, and $\geq 10 \mathrm{kDa}$ were separated via ultrafiltration. Cholesterol micelles were prepared in accordance with the method of Zhang et al ${ }^{[11]}$, with some modifications. Subsequently, $5 \mathrm{mg}$ of different $\mathrm{FPH}$ fractions was dissolved in $1 \mathrm{~mL}$ of micelle solution. The solution was shaken at $37^{\circ} \mathrm{C}$ for $24 \mathrm{~h}$ and centrifuged at 15,000 r/min for $60 \mathrm{~min}$. The supernatant fractions $(25 \mu \mathrm{L})$ were collected, and cholesterol concentrations were determined using a cholesterol assay kit (NJJC, Nanjing, China) by measuring the absorbance at $510 \mathrm{~nm}$. Finally, CMSR was calculated.

\subsection{LC-ESI-Orbitrap MS analysis of $\mathrm{FP}_{5}$}

The amino acid sequences of $\mathrm{FPH}_{5}$ were determined via HPLC-ESI-Orbitrap MS.

For the HPLC conditions, the sample was reconstituted in $0.1 \%$ aqueous formic acid, filtered through a $0.45 \mu \mathrm{m}$ microporous membrane, and separated by a reverse-phase $\mathrm{C}_{18}$ column. The mobile phase $\mathrm{A}$ comprised $0.1 \%$ aqueous formic acid, whereas the mobile phase $B$ comprised $0.1 \%$ formic acid in acetonitrile. The elution gradients with respect to mobile phase B were 0-5 min, 6-9\%; 5-20 min, 9-14\%; 20-50 min, 14-30\%; 50-58 min, 30-40\%; and 58-60 min, 40-95\%. The total elution time was 60 min,

and the column temperature was $30^{\circ} \mathrm{C}{ }^{[13]}$. The detection wavelength was $220 \mathrm{~nm}$, the injection volume was $10 \mu \mathrm{L}$, and the flow rate was $300 \mathrm{~nL} / \mathrm{min}$. The eluent was directly placed in the mass spectrometer system for analysis.

For ESI-Orbitrap MS conditions, the detection mode of ESI was in positive ion source, the capillary temperature was $250{ }^{\circ} \mathrm{C}$, the electrospray voltage was $2,100 \mathrm{~V}$, and the $\mathrm{m} / \mathrm{z}$ sweep range was $100-1,800$.

The original files of the mass spectrometer were processed with the supporting commercial software Maxquant (1.6.2.10). The obtained peptide sequences were compared with the amino acid sequences of the protein database (UniProtKB) to obtain the matched amino acid sequences. 


\subsection{Solid-phase peptide synthesis and CMSR of synthesized peptides}

The peptide amino acid sequences from $\mathrm{FPH}_{5}$ were synthesized by ChinaPeptides Co. (Shanghai, China) by using a solid-phase peptide synthesis (SSPS) procedure. The molecular masses and purities $(>97 \%)$ of the peptides were determined using an HPLC-MS system with a C18 column. A solution that consisted of $60 \% \mathrm{CH}_{3} \mathrm{OH}, 39.9 \% \mathrm{H}_{2} \mathrm{O}$, and $0.1 \% \mathrm{HCOOH}$ was used as the mobile phase. The flow rate was set to 0.5 $\mathrm{mL} / \mathrm{min}$, and the detection range was $\mathrm{m} / z$ 100-1800. The CMSR of the synthesized peptides was then evaluated.

\subsection{Preparation of IPPF antibody}

Immunization protocol: On the 1st day, the treated New Zealand rabbits were disinfected with alcohol, and $1 \mathrm{~mL}$ of antigen was added to $1 \mathrm{~mL}$ of Freund's complete adjuvant. The mixture was injected at multiple points (at least eight points) under the skin on the back of the neck. On the 15th day, the first booster immunization was performed, and $1 \mathrm{~mL}$ of antigen was added to $1 \mathrm{~mL}$ of Freund's incomplete adjuvant for emulsification then was injected at multiple sites under the skin on the back of the neck. On the 29th day, the second booster immunization was performed. On the 43rd day, the third booster immunization was performed. On the 53rd day, blood was taken from the carotid artery, and the rabbits were sacrificed. The rabbits' blood was placed overnight at $4^{\circ} \mathrm{C}$, centrifuged at $10000 \mathrm{r} / \mathrm{min}$ for $30 \mathrm{~min}$ at $4^{\circ} \mathrm{C}$, and the supernatant (serum, IPPF antibody) was collected.

Preparation of primary and secondary antibodies: After the IPPF antibody was purified, the antibody titer was determined by ELISA. The titer reached the target of about 1:1250. On the 63rd day, blood was collected via cardiac puncture. The primary antibody (IPPF antibody) used was rabbit antiserum, whereas the secondary antibody utilized was alkaline phosphatase-labeled primary antibody.

\subsection{Western blot analysis of IPPF expression in flaxseed protein}

The contents of flaxseed proteins in all samples were determined and diluted to $1 \mu \mathrm{g} / \mathrm{mL}$. Then, $5 \mathrm{~mL}$ of the diluted samples was mixed with an equal volume of the sample buffer ( $20 \%$ glycerol, $4 \%$ sodium dodecyl sulfate [SDS], $3 \%$ dithiothreitol, $0.002 \%$ bromophenol blue, and $0.125 \mathrm{M} \mathrm{Tris-HCl,} \mathrm{pH} 6.8$ ) and incubated at $98^{\circ} \mathrm{C}$ for $5 \mathrm{~min}$ to denature the proteins. The thermally denatured samples ( $10 \mu \mathrm{L} /$ lane, equal to $5 \mu \mathrm{g} /$ lane) were applied to $10 \%$ SDS-PAGE gels for $1 \mathrm{~h}$ at $50 \mathrm{~mA}$ and transferred onto a PVDF membrane (Hybond-P, GE Healthcare) for $1.5 \mathrm{~h}$ at $15 \mathrm{~mA}$. The membrane was then cut into two pieces according to the molecular weights of the flaxseed proteins. Both pieces of membrane were blocked with $5 \%(\mathrm{w} / \mathrm{v})$ skimmed milk in phosphate-buffered saline with Tween ${ }^{\circledR} 20$ (PBST) at room temperature for 1 $\mathrm{h}$ and then washed twice for $2 \mathrm{~min}$, once for $15 \mathrm{~min}$, and thrice for $5 \mathrm{~min}$ with PBST. The membrane with IPPF was probed with the primary antibody anti-IPPF (which was prepared in 2.3) and the secondary antibody at room temperature for $1 \mathrm{~h}$. After the specimen was washed three times, once for 2 min, twice for $15 \mathrm{~min}$, and thrice for 5 min with PBST, the proteins on the membranes were detected with ECL prime 
detection reagents (GE Healthcare, IL, US) and Image Quant LAS 4000 (GE Healthcare). Densitometry was performed to determine the amount of phosphorylation by using Image Quant TL 7.0 (GE Healthcare).

\subsection{Caco-2 and HepG2 cells culture}

Caco-2 and HepG2 cells were removed from liquid nitrogen and quickly placed in a preexisting tube after complete dissolution. The cells were obtained under sterile conditions and inoculated to $8-10 \mathrm{~mL}$ containing $90 \% \mathrm{MEM}+10 \%$ fetal bovine serum, penicillin (100 units $/ \mathrm{mL})$, and streptomycin $(100 \mu \mathrm{g} / \mathrm{mL})$. The culture medium was cultured in a $\mathrm{CO}_{2}$ incubator at $37^{\circ} \mathrm{C}$. After $24 \mathrm{~h}$, the culture medium was replaced, and the growth state of the cells was observed.

\subsection{Measurement of cell viability}

Caco-2 and HepG2 cells were digested by trypsin when the confluence reached $80 \%$. The cells were counted, and the cell concentration was adjusted to $2 \times 10^{4}$ cells $/ \mathrm{mL}$. The cells were seeded into a $12-$ well Transwell insert culture plate with $100 \mu \mathrm{L}$ of cells per well. Different concentrations of $100 \mu \mathrm{L}$ of IPPF were added per well and cultivated for $48 \mathrm{~h}$. After incubation, the cells were washed twice with PBS; then, $10 \mu \mathrm{L}$ of CCK-8 solution was added to each well and incubated at $37^{\circ} \mathrm{C}$ for $1-4 \mathrm{~h}$. OD at $450 \mathrm{~nm}$ was measured, and cell viability was calculated. The appropriate concentration was screened. The experiment had four groups: control; low-IPPF-dose group (Low, $200 \mu \mathrm{g} / \mathrm{mL}$ IPPF); medium-IPPF-dose group (Medium, $400 \mu \mathrm{g} / \mathrm{mL}$ IPPF); and high-IPPF-dose group (High, 800 jg/mL IPPF).

\subsection{Establishment of a Caco-2 cell monolayer model in vitro [13]}

Caco-2 cells were digested with trypsin when the confluence reached $80 \%$. The cells were counted, and cell concentration was adjusted to $8 \times 10^{4}$ cells $/ \mathrm{mL}$. The cells were seeded into a 12-well Transwell insert culture plate with $500 \mu \mathrm{L}$ of cells per well, and $1 \mathrm{~mL}$ of the culture solution was added to the basal side. The culture media were changed $24 \mathrm{~h}$ after inoculation, and the culture medium was changed every 3 days. Transepithelial electrical resistance (TEER) was measured using Millicell ERS, and alkaline phosphatase (AKP) was determined using an AKP kit (NJJC, Nanjing, China).

\subsection{Cholesterol transport contents of IPPF in Caco-2 cells}

IPPF concentration was determined according to cell viability. The configuration of cholesterol micromicelles was determined in accordance with the slightly modified method of Zhang et al. ${ }^{[12]}$. In the apical side (AP) - basolateral side (BL) transport experiment, after the transport model was established, $0.4 \mathrm{~mL}$ of IPPF and cholesterol micelle solution was added to the AP side, and $1.2 \mathrm{~mL}$ of HBSS was added to the BL side. The 12-well Transwell TM culture plate was covered and then shaken at $50 \mathrm{r} / \mathrm{min}$ at $37^{\circ} \mathrm{C}$. Then, $0.1 \mathrm{~mL}$ of the receiving solution was collected, and $0.1 \mathrm{~mL}$ of the blank receiving solution was added. Subsequently, $0.5 \mathrm{~mL}$ of HBSS was added to wash the cell layer three times. The cells were lysed with lysate on ice. Afterward, the lysate was sonicated to make a uniform solution. A 22-NBD- 
cholesterol kit (NJJC, Nanjing, China) was used to determine the contents of cholesterol-transport contents.

\subsection{Western blot analysis of Caco-2 cells}

The protein levels of NPC1L1 and ABCG5/8 in the microsomal fraction were determined through Western blot analysis with $\beta$-actin as an internal reference. Cells were lysed by cell lysate to extract proteins. The specific experimental method was similar to that described Sect. 2.7.

\subsection{Determination of HepG2 cellular total cholesterol contents}

First, HepG2 cells in a 24-well plate at a density of $2.5 \times 10^{5}$ cells/well were treated with different IPPF concentrations for $24 \mathrm{~h}$. After each treatment, the total cholesterol of different groups was determined by a cholesterol kit (NJJC, Nanjing, China) following the manufacturer's protocol.

\subsection{Determination of mRNA levels in HepG2 cells}

Total RNA was isolated from HepG2 cells by using the RNeasy mini kit (NJJC, Nanjing, China) following the manufacturer's instructions. Complementary DNA (cDNA) was synthesized from $1.0 \mu \mathrm{g}$ total RNA by using the Transcriptor First Strand cDNA Synthesis Kit (Roche, Berlin, Germany). Gene expression levels were analyzed via quantitative real-time reverse transcription polymerase chain reaction with a SYBR® Premix EX Taq II Kit and a Thermal Cycler Mx3000P QPCR System. mRNA levels were normalized using the $\beta$-actin $(A c t b)$ gene as an internal standard. The primer sequences and annealing temperatures used for the analysis are shown in Table 1.

Table 1

Primers for real-time RT-PCR

\begin{tabular}{|lll|}
\hline Gene name & Forward primer & Reverse primer \\
\hline Actb & TCAGGTCATCACTATCGGCA & TCATGGATGCCACAGGATTC \\
\hline Hmgcr & TGTGGGAACGGTGACACTTA & GCTGACGCAGGTTCTGGAA \\
\hline SREBP-2 & CTGGCAAATCAAAAGAACAAGC & GGACATTCTGATTAAAGTCCTCGA \\
\hline LXR-a & ATGGACACCTACATGCGTC & CTTCAGGCGGATCTGTTCTT \\
\hline CYP7A1 & CTGTCATACCACAAAGTCTTATGTCA & ATGCTTCTGTGTCCAAATGCC \\
\hline Soat1 & GATGGGGTTATGTTGCTATGC & GGGCTCCTGTTTGATATTCCG \\
\hline
\end{tabular}

\subsection{Statistical analysis}

The experiments were conducted in triplicate, and data were expressed as mean \pm standard deviation. One-way ANOVA and Duncan's new multiple-range test were performed to determine significant differences among the means at $p<0.05$. 


\section{Results}

\subsection{CMSR of different FPs fraction}

The $\mathrm{FPH}_{3}$ fraction had the lowest the cholesterol-lowering activity, and the CMSR was only $27.07 \%$ (Table 2). The $\mathrm{FP}_{5}$ fraction had the highest cholesterol-lowering activity, and the CMSR was $72.39 \%$.

Table 2

The relative molecular weight distribution and CMSR of various fractions after ultrafiltration of FP

\begin{tabular}{|lllll|}
\hline Groups & Molecular weight (kDa) & Percent /\% & purity & CMSR/\% \\
\hline $\mathrm{FP}_{1}$ & $\geq 10$ & 5.09 & 65.23 & $50.95 \pm 6.74$ \\
\hline $\mathrm{FP}_{2}$ & $5 \sim 10$ & 3.38 & 69.76 & $35.12 \pm 5.33$ \\
\hline $\mathrm{FP}_{3}$ & $3 \sim 5$ & 3.69 & 60.33 & $27.07 \pm 9.01$ \\
\hline $\mathrm{FP}_{4}$ & $1 \sim 3$ & 22.30 & 59.13 & $45.08 \pm 8.37$ \\
\hline $\mathrm{FP}_{5}$ & $\leq 1$ & 65.54 & 66.04 & $\mathbf{7 2 . 3 9} \pm 5.53$ \\
\hline Values are mean $\pm \mathrm{SD}$. & & & \\
\hline
\end{tabular}

\subsection{Amino acid sequences of $\mathrm{FP}_{5}$}

Eleven peptides were identified from $\mathrm{FP}_{5}$ (Fig. 1 and Table 3). These peptides were characterized by high contents of leucine $(\mathrm{L})$, proline $(\mathrm{P})$, and glycine $(\mathrm{G})$. Characteristic sequences comprising PP, $L L$, and $L P$ were observed. Amino acid sequences from $\mathrm{FP}_{5}$ were a) QDIQQQGQQQEVER, b) RDLPGQCGTQPSRCQ, c) SECTCRGLE, d) QEIQQQGQQQEVQ, e) VHPSGLPGEQTGHNT, f) LLGTL, g) LNFF, h) IIPAF, i) IPPF, j) IIF, and k) LLGA. 
Table 3

Structural Characterization of FP5

\begin{tabular}{|c|c|c|c|}
\hline $\begin{array}{l}\text { Serial } \\
\text { number }\end{array}$ & $\begin{array}{l}\text { Molecular } \\
\text { weight }\end{array}$ & Peptide & Protein hits \\
\hline \multirow[t]{2}{*}{ ० } & \multirow[t]{2}{*}{1715.84} & \multirow[t]{2}{*}{ QDIQQQGQQQEVER } & $\begin{array}{l}\text { Flaxseed (Linum usitatissimum) Conlinin2 (121- } \\
\text { 135) }\end{array}$ \\
\hline & & & GQMRQDIQQQGQQQEVERWVQQAK \\
\hline \multirow[t]{2}{*}{ ( } & \multirow[t]{2}{*}{1761.82} & \multirow[t]{2}{*}{ DLPGQCGTQPSRC } & $\begin{array}{l}\text { Flaxseed (Linum usitatissimum) Conlinin2 (144- } \\
\text { 159) }\end{array}$ \\
\hline & & & QVARDLPGQCGTQPSRCQLQGQQQSAWF \\
\hline \multirow[t]{2}{*}{ प } & \multirow[t]{2}{*}{1112.46} & \multirow[t]{2}{*}{ SECTCRGLE } & $\begin{array}{l}\text { Flaxseed (Linum usitatissimum) Conlinin2 (105- } \\
\text { 114) }\end{array}$ \\
\hline & & & KQLRSECTCRGLERAIGQMR \\
\hline \multirow[t]{2}{*}{ ( } & \multirow[t]{2}{*}{1571.79} & \multirow[t]{2}{*}{ QEIQQQGQQQEVQ } & $\begin{array}{l}\text { Flaxseed (Linum usitatissimum) Conlinin1(121- } \\
\text { 135) }\end{array}$ \\
\hline & & & AIGQMRQEIQQQGQQQEVQRWIQQA \\
\hline \multirow[t]{2}{*}{ ( } & \multirow[t]{2}{*}{1532.75} & \multirow[t]{2}{*}{ VHPSGLPGEQTGHNT } & $\begin{array}{l}\text { Flaxseed (Linum usitatissimum) Late embryo } \\
\text { development group } 1 \text { protein-embryo development } \\
(137-152)\end{array}$ \\
\hline & & & DEGVARVHPSGLPGEQTGHNTRTGGTGTGH \\
\hline \multirow[t]{2}{*}{ ( } & \multirow[t]{2}{*}{516.340} & \multirow[t]{2}{*}{ LLGTL } & $\begin{array}{l}\text { Flaxseed (Linum usitatissimum) NADH } \\
\text { dehydrogenase subunit F (114-119) }\end{array}$ \\
\hline & & & QSAFLLGTLSLCGIPPFACF \\
\hline \multirow[t]{2}{*}{ ( } & \multirow[t]{2}{*}{540.288} & \multirow[t]{2}{*}{ LNFF } & $\begin{array}{l}\text { Flaxseed (Linum usitatissimum) NADH } \\
\text { dehydrogenase subunit } F(660-664)\end{array}$ \\
\hline & & & AXXLNFFDXDX \\
\hline \multirow[t]{2}{*}{ ( } & \multirow[t]{2}{*}{560.349} & \multirow[t]{2}{*}{ IIPAF } & $\begin{array}{l}\text { Flaxseed (Linum usitatissimum) NADH } \\
\text { dehydrogenase subunit } F(11-15)\end{array}$ \\
\hline & & & MQHXTYSYSWIIPAFTLLVP \\
\hline \multirow[t]{2}{*}{ ( } & \multirow[t]{2}{*}{473.283} & \multirow[t]{2}{*}{ IPPF } & $\begin{array}{l}\text { Flaxseed (Linum usitatissimum) NADH } \\
\text { dehydrogenase subunit F (423-426) }\end{array}$ \\
\hline & & & LSLCGIPPFACFW \\
\hline \multirow[t]{2}{*}{ 口 } & \multirow[t]{2}{*}{392.256} & \multirow[t]{2}{*}{ IIF } & $\begin{array}{l}\text { Flaxseed(Linum usitatissimum) LINUS Chloroplast } \\
\text { envelope membrane protein(17-19) }\end{array}$ \\
\hline & & & FYLTSXIIFLPWWIS \\
\hline
\end{tabular}




\begin{tabular}{|llll|}
\hline $\begin{array}{l}\text { Serial } \\
\text { number }\end{array}$ & $\begin{array}{l}\text { Molecular } \\
\text { weight }\end{array}$ & Peptide & Protein hits \\
\hline$\square$ & 373.247 & LLGA & $\begin{array}{l}\text { Flaxseed (Linum usitatissimum) NADH } \\
\text { dehydrogenase subunit F (18-21) }\end{array}$ \\
\hline \begin{tabular}{l} 
VGIITVLLGATLALAQ \\
\hline
\end{tabular} & & & \\
\hline
\end{tabular}

\subsection{CMSR of SSPS peptides from $\mathrm{FP}_{5}$}

The purities of all synthetic peptides were greater than 97\% (Table 4). Among the groups, SECTCRGLE had the lowest cholesterol-lowering, and the CMSR of SECTCRGLE was only 53.39\%. IPPF had the highest cholesterol-lowering activity, and the CMSR of IPPF was $93.47 \%$.

Table 4

CMSR of peptides from $\mathrm{FP}_{5}$ synthesized by solid phase in vitro

\begin{tabular}{|lll|}
\hline Peptide & Purity & CMSR/\% \\
\hline QDIQQQGQQQEVER & 99.13 & $77.37 \pm 3.98$ \\
\hline DLPGQCGTQPSRC & 98.45 & $70.94 \pm 6.60$ \\
\hline SECTCRGLE & 98.64 & $53.39 \pm 1.00$ \\
\hline QEIQQQGQQQEVQ & 97.83 & $86.20 \pm 2.61$ \\
\hline VHPSGLPGEQTGHNT & 99.07 & $60.56 \pm 2.54$ \\
\hline LLGTL & 98.92 & $88.02 \pm 1.80$ \\
\hline LNFF & 97.66 & $80.31 \pm 1.39$ \\
\hline IIPAF & 99.45 & $82.81 \pm 1.8$ \\
\hline IPPF & 98.78 & $93.47 \pm 2.3$ \\
\hline IIF & 99.14 & $80.31 \pm 1.4$ \\
\hline LLGA & 98.05 & $87.06 \pm 1.5$ \\
\hline Values are mean \pm SD. & & \\
\hline
\end{tabular}

\subsection{Protein characterization and IPPF-specific antibody Western blot reaction}

Five bands with a molecular weight of $35,23,20,12$, and $11 \mathrm{kDa}$ were separated from the flaxseed protein (Fig. 2A). The IPPF-specific antibody specifically bonded to the target flaxseed peptides, IPPF, with a molecular weight ranging from $17 \mathrm{kDa}$ to $26 \mathrm{kDa}$ (Fig. 2B). This result showed that the flaxseed peptide IPPF existed in the flaxseed protein. 


\subsection{Effects of different IPPF concentrations on Caco-2 and HepG2 cell viability}

Different IPPF concentrations did not exhibit toxicity to Caco-2 and HepG2 cells (Fig. 3). Cell viability was consistently maintained at over $95 \%$ with IPPF concentration increased, with slightly affected cell survival.

\subsection{Establishment of Caco-2 cell transmembrane transport model}

The TEER of cells is measured to evaluate the compactness and completeness of a cell model ${ }^{[14]}$. The TEER ranging from $200 \Omega \cdot \mathrm{cm}^{2}$ to $1000 \Omega \cdot \mathrm{cm}^{2}$ indicates that cell monolayer models are compact and complete ${ }^{[14]}$. The TEER slowly increased in the 1 st week and reached only $60.48 \Omega \cdot \mathrm{cm}^{2}$ on the 6 th day (Fig. 4). Thereafter, the TEER rapidly increased and reached $430.08 \Omega \cdot \mathrm{cm}^{2}$ on the 15 th day and then further increased to $529.76 \Omega \cdot \mathrm{cm}^{2}$. Alkaline phosphatase (AKP) is used to evaluate the degree of cell

differentiation in AP-BL transport experiments ${ }^{[15]}$. AKP activity between the AP and $B L$ sides from days 5 to 9 was not substantially different. However, AKP activity significantly increased from day 13 . By the 21 st day, the AKP activity ratio reached over two times between the AP and BL sides. Cell growth morphology was observed under an inverted microscope. After 21 days of culture, Caco- 2 cells formed dense cell monolayers (Fig. 4). The in vitro Caco-2 cell transmembrane transport model was established.

\subsection{Effects of IPPF on cholesterol transport contents and proteins levels of intestinal cholesterol absorption in Caco-2 cells}

Low, medium, and high doses of IPPF significantly reduced the cholesterol transport contents in Caco-2 cells in a dose-dependent manner compared with that in the control group (Fig. 5A). The cholesterol transport content in the high-dose group was $0.73 \mathrm{mmol}$, and it decreased by $1.52 \mathrm{mmol}$ compared with that in the control group. IPPF significantly decreased the protein levels of NPC1L1 in a dose-dependent manner (Figs. 5B and 5E). There was no significant difference of NPC1L1 was observed between the low and medium groups. The protein levels of ABCG5 and ABCG8 significantly increased in a dose-dependent manner (Figs. 5C, 5D and 5E). The protein levels of ABCG8 have no difference between the low and medium groups.

3.8 Effects of IPPF on the total cholesterol contents and mRNA levels of hepatic cholesterol metabolism in HepG2 cells 
Low and medium groups of IPPF significantly decreased the total cholesterol contents in HepG2 cells compared with that in the control group (Fig. 6A). No significant difference in total cholesterol content was observed between the high and medium groups. IPPF significantly decreased the mRNA levels of HMGCR and SREBP-2 in the low and medium groups compared with that in the control group (Fig. 6B). No significant difference in the mRNA levels of Hmgcrand Srebp-2 was observed between the high and medium groups. IPPF also significantly increased the mRNA levels of $L x r a$ and Cyp7a1 in the mediumdose group compared with that in the control group. No significant difference in the mRNA expression of Soat1 was found among the different groups.

\section{Discussion}

The biological functions of a peptide are determined by their amino acid sequences and spatial structure. In this study, the amino acid sequences of $\mathrm{FP}_{5}$ were detected via LC-ESI-Orbitrap MS and eleven peptides were determined. The amino acid sequences of these 11 peptides contained high contents of hydrophobic amino acids. The molecular weight of the 11 peptides ranged from $350 \mathrm{Da}$ to $1700 \mathrm{Da}$. Several studies reported that food-derived peptides have cholesterol-lowering activities with low molecular weights and continuous hydrophobic amino acids ${ }^{[16]}$. The IPP and VPP from milk peptides have cholesterol-lowering effects ${ }^{[17]}$. Takeuchi $A$ et al. ${ }^{[18]}$ isolated IIAEK from bovine milk $\beta$-lactoglobulin and improved intestinal cholesterol metabolism with a specific activation of IAP and downregulation of ABCA1. Soybean peptides, WGAPSL, also been reported to reduce cholesterol transport content in Caco-2 and HepG2 cells ${ }^{[19]}$. The above studies showed that cholesterol-lowering peptides all have continuous hydrophobic amino acid sequences and are tripeptide or tetrapeptide. These results were completely consistent with this research. Cholesterol is absorbed in the intestine in the form of cholesterol micelles and then transport into blood. CMSR is an important indicator for evaluating cholesterol-lowering activity in vitro ${ }^{[20]}$. The peptides whose amino acid sequences were determined herein were synthesized by SPPS and CMSR of these peptides was determined. The CMSR of SPPS peptides were higher than that of $\mathrm{FP}_{5}$. The peptide synthesized by SPPS could not simulate the secondary and tertiary structures of the peptides. Thus, a remarkable increase of CMSR in synthetic peptides might be related to purity of peptides. Specific mechanisms, such as molecular docking between peptides and cholesterol molecule, would be studied in a follow-up study.

Intestinal cholesterol absorption and hepatic cholesterol metabolism are considered as the main regulating pathways of blood cholesterol and lipoprotein levels ${ }^{[21]}$. Thus, Caco-2 and HepG2 cells were used as cells models to investigate the effects of IPPF on modulating intestinal cholesterol absorption and hepatic cholesterol metabolism. The effect of IPPF on intestinal cholesterol absorption was investigated in Caco- 2 cells. NPC1L1 is a transporter protein mainly expressed in intestinal tract epithelial cells and is considered as the main cholesterol absorption regulator ${ }^{[22]}$. NPC1L1 has the N-terminal domain special structure, namely the $\mathrm{N}$-terminal domain, which can specifically sense to cholesterol then 
form endocytosis of NPC1L1-flotillin-cholesterol membrane microdomains to mediates endocytosis, which is an early step in cholesterol absorption. ${ }^{[23]}$. A previous study reported that inhibiting the NPC1L1 expression can effectively prevent cholesterol absorption in intestine ${ }^{[24]}$. ABCG5 and ABCG8 are expressed in tissue-specific manner in the intestines and are considered as a half transporter to limit cholesterol intestinal absorption and promote the biliary excretion of sterol and cholesterol [25]. Overexpression of ABCG5 and ABCG8 reduces fractional absorption of dietary cholesterol and promotes biliary cholesterol secretion in mice ${ }^{[26]}$. In this study, the cholesterol transportation contents decreased after high IPPF induction in Caco-2 cells. IPPF induction also down-regulated the protein expression of NPC1L1 and up-regulated the protein expression of ABCG5/8. Our study confirmed that IPPF can inhibit cholesterol absorption in Caco-2 cells through regulating cholesterol transporter of NPC1L1 and ABCG5/8. A previous study reported that the milk casein-derived peptides decrease cholesterol micellar solubility and cholesterol intestinal absorption in Caco-2 cells by downregulating NPC1L1 expression and upregulating $A B C G 8{ }^{[27]}$. This result was completely consistent with the findings of this study. IPPF could be used as an intestinal cholesterol absorption inhibitor to reduce dietary cholesterol absorption.

The effect of IPPF on hepatic cholesterol metabolism was investigated in HepG2 cells. The hepatic cholesterol metabolism homeostasis is preserved as a result of balance among the processes of cholesterol synthesis and bile acid synthesis ${ }^{[28]}$. The cholesterol synthesis is regulated by SREBP2 and HMGCR. SREBP2 (gene name Srebp2) binds to the sterol regulatory elements (SREs) in the promoters of its target genes and activates the transcription of HMGCR ${ }^{[29]}$. HMGCR (gene name $\mathrm{Hmgcr}$ ) is the ratelimiting enzyme of hepatic cholesterol synthesis ${ }^{[30]}$. In this study, we observed the total cholesterol contents in HepG2 cells significantly decreased after IPPF treatment. IPPF significantly decreased the mRNA levels of Srebp-2 and Hmgcr in the low and medium groups compared with control group. We confirm that IPPF can reduce liver cholesterol synthesis through inhibiting the SREBP-2-regulated mevalonate (HMGCR) pathway (Fig. 7). The synthesis and excretion of bile acids comprise the major pathway of cholesterol catabolism. CYP7A1 (gene name Cyp7a1) is the rate-limitation enzyme in the first step of bile acid synthesis ${ }^{[31]}$. Lxra (gene name $L x r a$ ) has been proven as the transcription factor for CYP7A ${ }^{[32]}$. IPPF significantly increased the mRNA levels of $L x r a$ and $C y p 7 a 1$ in the medium-dose group compared with that in the control group. HepG2 cells can synthesizes bile acids, but the levels of bile acids are low and defective in oxidation of the side chain, conjugation, and transport ${ }^{[33]}$. In this study, the content of bile acid in Hepg2 cells was not determined due to the limitation of detection accuracy. Thus, we cannot determine whether the bile acids synthesis was promoted only through the increase of Cyp7a1 mRNA levels. Lammi ${ }^{[34]}$ found that three peptides from soy glycinin can modulate cholesterol metabolism in HepG2 cells by activating the LDLR-SREBP2 pathway. Another study reported that peptides derived from cowpea bean can reduce the mRNA expression of Srebp2 and Hmgcr in HepG2 cells ${ }^{[35]}$. These studies indicated that plant-derived peptides have similar mechanism on reducing cholesterol synthesis in liver. IPPF could be used as a hepatic cholesterol synthesis inhibitor to prevent hepatic cholesterol accumulation and hypercholesterolemia. 
In conclusion, 11 peptides with cholesterol-lowering activity were isolated from $\mathrm{FP}_{5}$. IPPF, with the highest CMSR, inhibits cholesterol intestinal absorption through modulating the protein expression levels of NPC1L1 and ABCG5/8 in Caco-2 cells. IPPF also reduces cholesterol synthesis through inhibiting the SREBP2-regulated mevalonate pathway in HepG2 cells. The study confirmed that IPPF is an inhibitor of intestinal cholesterol absorption and hepatic cholesterol synthesis. IPPF is a notable new food-derived cholesterol-lowering ingredient without any side effects and provide a nutritional therapy component for hypercholesterolemia.

\section{Abbreviations}

HMGCR, 3-hydroxy-3-methylglutaryl coenzyme A reductase; SREBP-2, Sterol regulatory element-binding protein 2; CYP7A1, Cholesterol 7 alpha-hydroxylase; LXRa, Liver X receptor a; SOAT1, Sterol Oacyltransferase; NPC1L1, Niemann-Pick C1-like 1; ABCG5/G8, ATP binding cassette transporters G5 and G8; ACAT1, acetyl-coA cholesterol acyltransferase.

\section{Declarations}

\section{Availability of data and materials}

The data used and analyzed in this study are available from the corresponding author upon reasonable request.

\section{Conflict of interest}

The authors have no conflicts of interest to declare.

\section{Author contributions}

Data curation, Yuan Xingyu, Li Xuexin and Liu Xiaojing; Formal analysis, Yuan Xingyu; Funding acquisition, Bao Xiaolan; Investigation, Yuan Xingyu, Li Xuexin and Liu Xiaojing; Project administration, Bao Xiaolan; Resources, Bao Xiaolan; Writing - original draft, Yuan Xingyu,Bao Xiaolan; Writing - review \& editing, Bao Xiaolan, Yuan Xingyu.

\section{Funding source}

This work was financially supported by the National Natural Science Foundation of China (No. 31860423) and Inner Mongolia Autonomous Region Science and Technology Plan Project (No. 2020GG0064)

\section{Acknowledgements}

The authors would like to thank Shinewrite (www.shinewrite.com) for English language editing. 


\section{References}

1. Tabas I. Cholesterol in health and disease[J]. J Clin Investig. 2002;110(5):583-90.

2. Rooy MJ, Pretorius E, Obesity. Hypertension and hypercholesterolemia as risk factors for atherosclerosis leading to ischemic events[J]. Curr Med Chem. 2014;21(19):2121-9.

3. Grundy SM, Ahrens EH Jr, Davignon J. The interaction of cholesterol absorption and cholesterol synthesis in man[J]. J Lipid Res. 1969;10(3):304-15.

4. Wilson MD, Rudel LL. Review of cholesterol absorption with emphasis on dietary and biliary cholesterol[J]. Journal of lipid research. 1994;35(6):943-55.

5. Weingärtner $\mathrm{O}$, Lütjohann $\mathrm{D}$, Böhm M, et al. Relationship between cholesterol synthesis and intestinal absorption is associated with cardiovascular risk[J]. Atherosclerosis. 2010;210(2):362-5.

6. Armitage J. The safety of statins in clinical practice[J]. The Lancet. 2007;370(9601):1781-90.

7. Parolini C, Rigamonti E, Marchesi M, et al. Cholesterol-lowering effect of dietary Lupinus angustifolius proteins in adult rats through regulation of genes involved in cholesterol homeostasis[J]. Food Chem. 2012;132(3):1475-9.

8. Yang N, Li YM, Zhang K, et al. Hypocholesterolemic activity of buckwheat flour is mediated by increasing sterol excretion and down-regulation of intestinal NPC1L1 and ACAT2[J]. Journal of Functional Foods. 2014;6:311-8.

9. Shim YY, Gui B, Arnison PG, et al. Flaxseed (Linum usitatissimum L.) bioactive compounds and peptide nomenclature: A review[J]. Trends Food Sci Technol. 2014;38(1):5-20.

10. Salma NU, Govindaraju K, Kumar BSG, et al. Ameliorative effect of enhanced Fischer ratio flaxseed protein hydrolysate in combination with antioxidant micronutrients on ethanol-induced hepatic damage in a rat model[J]. British Journal of Nutrition, 1-15.

11. Ume Salma N, Serva Peddha M, Aswathanarayana Setty JL. Ameliorative effect of flaxseed (Linum usitatissimum) and its protein on ethanol-induced hepatotoxicity in Wistar rats[J]. J Food Biochem. 2019;43(12):e13047.

12. Zhang H, Yokoyama WH, Zhang H. Concentration-dependent displacement of cholesterol in micelles by hydrophobic rice bran protein hydrolysates[J]. J Sci Food Agric. 2012;92(7):1395-401.

13. Bao X, Yuan X, Feng G, et al. Structural characterization of calcium-binding sunflower seed and peanut peptides and enhanced calcium transport by calcium complexes in Caco-2 cells[J]. J Sci Food Agric. 2021;101(2):794-804.

14. Ferrell N, Desai RR, Fleischman AJ, et al. A microfluidic bioreactor with integrated transepithelial electrical resistance (TEER) measurement electrodes for evaluation of renal epithelial cells[J]. Biotechnol Bioeng. 2010;107(4):707-16.

15. Lallès JP. Intestinal alkaline phosphatase: multiple biological roles in maintenance of intestinal homeostasis and modulation by diet[J]. Nutrition reviews. 2010;68(6):323-32.

16. Singh BP, Aluko RE, Hati S, et al. Bioactive peptides in the management of lifestyle-related diseases: Current trends and future perspectives[J]. Critical Reviews in Food Science and Nutrition, 2021: 1-14. 
17. Turpeinen AM, Ikonen $M$, Kivimäki AS, et al. A spread containing bioactive milk peptides lle-Pro-Pro and Val-Pro-Pro, and plant sterols has antihypertensive and cholesterol-lowering effects[J]. Food \& function, 2012, 3(6): pp. 621-7.

18. Takeuchi A, Hisamatsu K, Okumura N, et al. IIAEK Targets Intestinal Alkaline Phosphatase (IAP) to Improve Cholesterol Metabolism with a Specific Activation of IAP and Downregulation of ABCA1[J]. Nutrients. 2020;12(9):2859.

19. Zhang H, Duan Y, Feng Y, et al. Transepithelial Transport Characteristics of the Cholesterol-Lowing Soybean Peptide, WGAPSL, in Caco-2 Cell Monolayers[J]. Molecules. 2019;24(15):2843.

20. Field FJ, Born E, Mathur SN. Effect of micellar beta-sitosterol on cholesterol metabolism in CaCo-2 cells[J]. Journal of lipid research. 1997;38(2):348-60.

21. Millar JS, Cuchel M. Cholesterol metabolism in humans: a review of methods and comparison of results[J]. Curr Opin Lipidol. 2018;29(1):1-9.

22. Davis HR, Zhu L, Hoos LM, et al. Niemann-Pick C1 Like 1 (NPC1L1) is the intestinal phytosterol and cholesterol transporter and a key modulator of whole-body cholesterol homeostasis[J]. J Biol Chem. 2004;279(32):33586-92.

23. Zhang JH, Ge L, Qi W, et al. The N-terminal domain of NPC1L1 protein binds cholesterol and plays essential roles in cholesterol uptake[J]. J Biol Chem. 2011;286(28):25088-97.

24. Davis HR Jr, Basso F, Hoos LM, et al. Cholesterol homeostasis by the intestine: lessons from Niemann-Pick C1 Like 1 (NPC1L1) [J]. Atherosclerosis Supplements. 2008;9(2):77-81.

25. Wang J, Mitsche MA, Lütjohann D, et al. Relative roles of ABCG5/ABCG8 in liver and intestine[J]. Journal of lipid research. 2015;56(2):319-30.

26. Yu L, Li-Hawkins J, Hammer RE, et al. Overexpression of ABCG5 and ABCG8 promotes biliary cholesterol secretion and reduces fractional absorption of dietary cholesterol[J]. J Clin Investig. 2002;110(5):671-80.

27. Jiang $X$, Pan D, Zhang T, et al. Novel milk casein-derived peptides decrease cholesterol micellar solubility and cholesterol intestinal absorption in Caco-2 cells[J]. J Dairy Sci. 2020;103(5):3924-36.

28. Yuan X, Minobe Y, Tanaka Y, et al. a-Globulin-rich rice cultivar, low glutelin content-1 (LGC-1), decreases serum cholesterol concentration in exogenously hypercholesterolemic rats[J]. Journal of the Science of Food and Agriculture; 2021.

29. Chen L, Ma MY, Sun M, et al. Endogenous sterol intermediates of the mevalonate pathway regulate HMGCR degradation and SREBP-2 processing[J]. Journal of lipid research. 2019;60(10):1765-75.

30. Ma S, Sun W, Gao L, et al. Therapeutic targets of hypercholesterolemia: HMGCR and LDLR[J]. Diabetes, metabolic syndrome and obesity: targets and therapy, 2019, 12: 1543.

31. Li T, Owsley E, Matozel M, et al. Transgenic expression of cholesterol 7a-hydroxylase in the liver prevents high-fat diet-induced obesity and insulin resistance in mice[J]. Hepatology. 2010;52(2):678-90. 
32. Chiang JYL, Kimmel R, Stroup D. Regulation of cholesterol 7a-hydroxylase gene (CYP7A1) transcription by the liver orphan receptor (LXRa)[J]. Gene. 2001;262(1-2):257-65.

33. Javitt NB. Hep G2 cells as a resource for metabolic studies: lipoprotein, cholesterol, and bile acids[J]. FASEB J. 1990;4(2):161-8.

34. Lammi C, Zanoni C, Scigliuolo GM, et al. Lupin peptides lower low-density lipoprotein (LDL) cholesterol through an up-regulation of the LDL receptor/sterol regulatory element binding protein 2 (SREBP2) pathway at HepG2 cell line[J]. J Agric Food Chem. 2014;62(29):7151-9.

35. Marques MR, Cerda A, Fontanari GG, et al. Transport of cowpea bean derived peptides and their modulator effects on mRNA expression of cholesterol-related genes in Caco-2 and HepG2 cells[J]. Food Res Int. 2018;107:165-71.

\section{Figures}



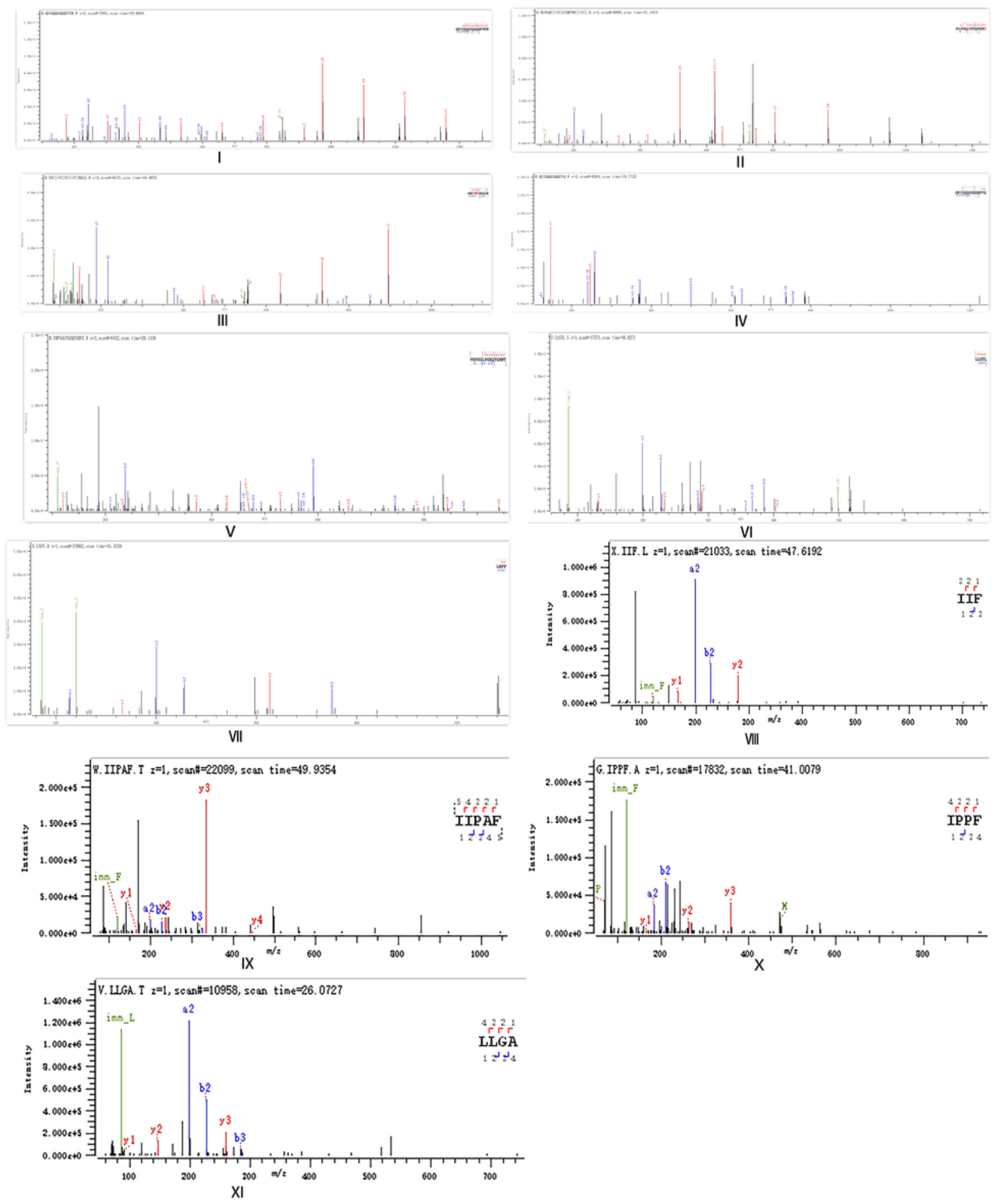

\section{Figure 1}

MS spectrum of eleven peptides identification from FP5 


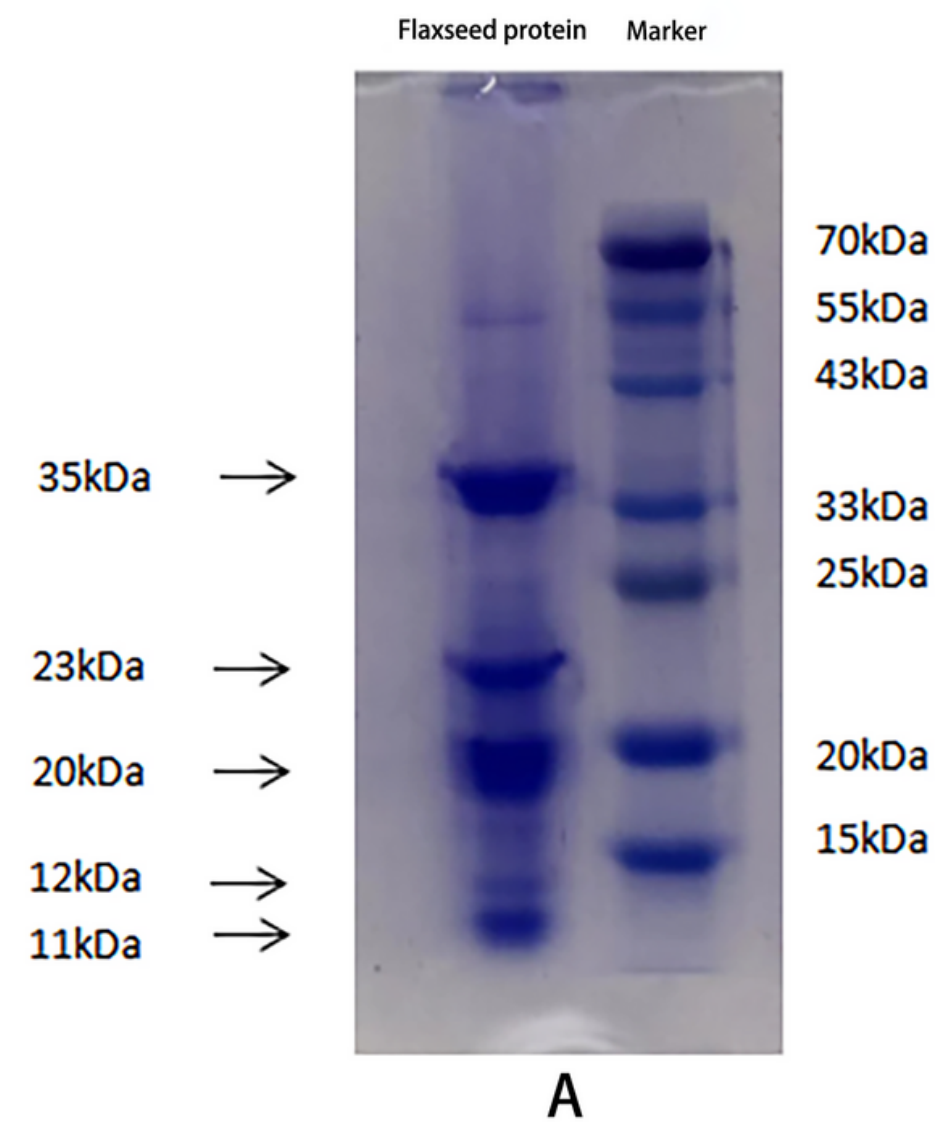

SDS-PAGE separation of Flaxseed protein

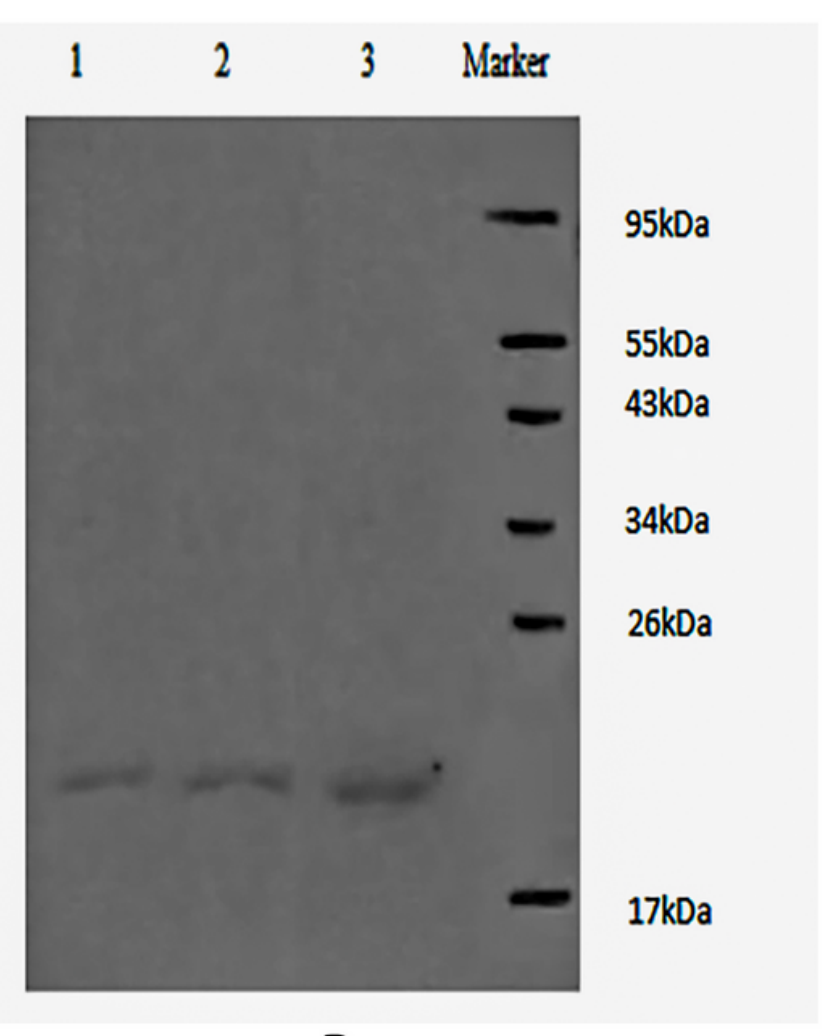

B

Antibody expression of IPPF in flaxseed protein

Figure 2

SDS-PAGE separation effect of flaxseed protein (A) and the expression of IPPF in flaxseed protein (B) 


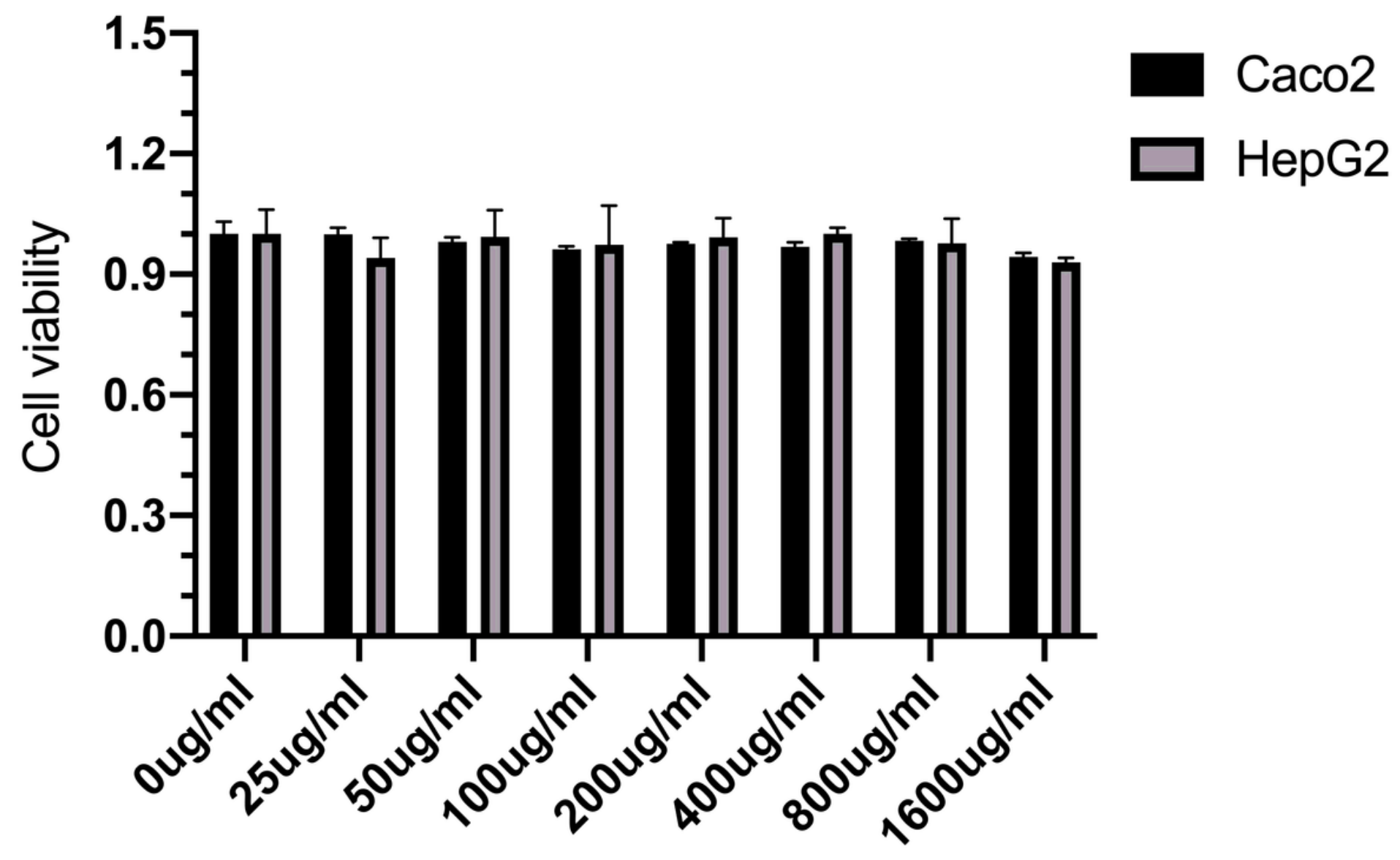

Figure 3

Effect of different concentrations of IPPF on cell viability 


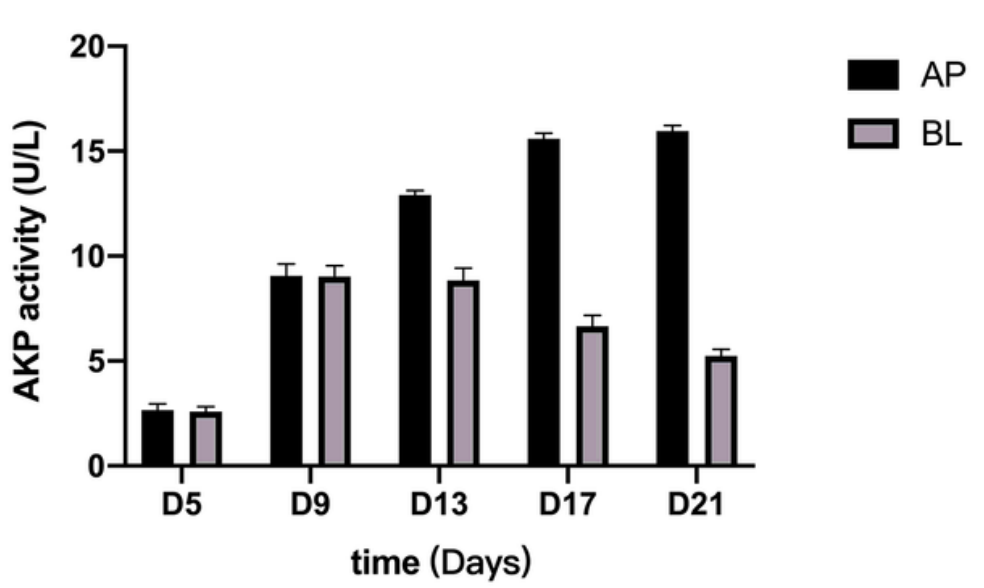

TEER value of Caco- 2 cell monolayer model at different culture time

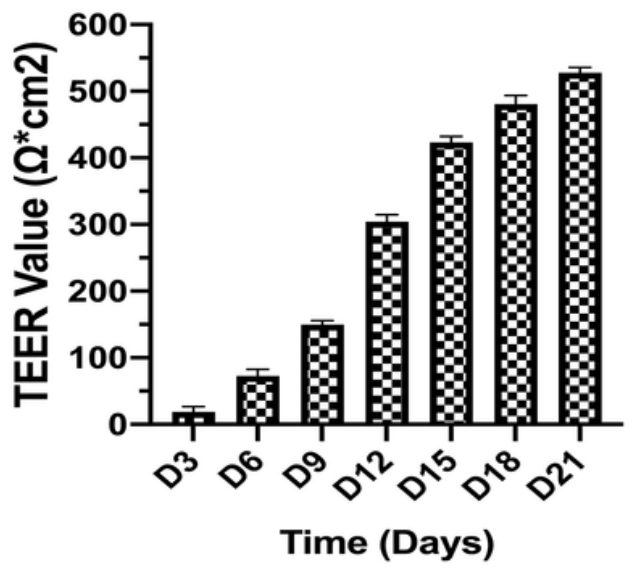

TEER value of Caco- 2 cell monolayer model at different culture time
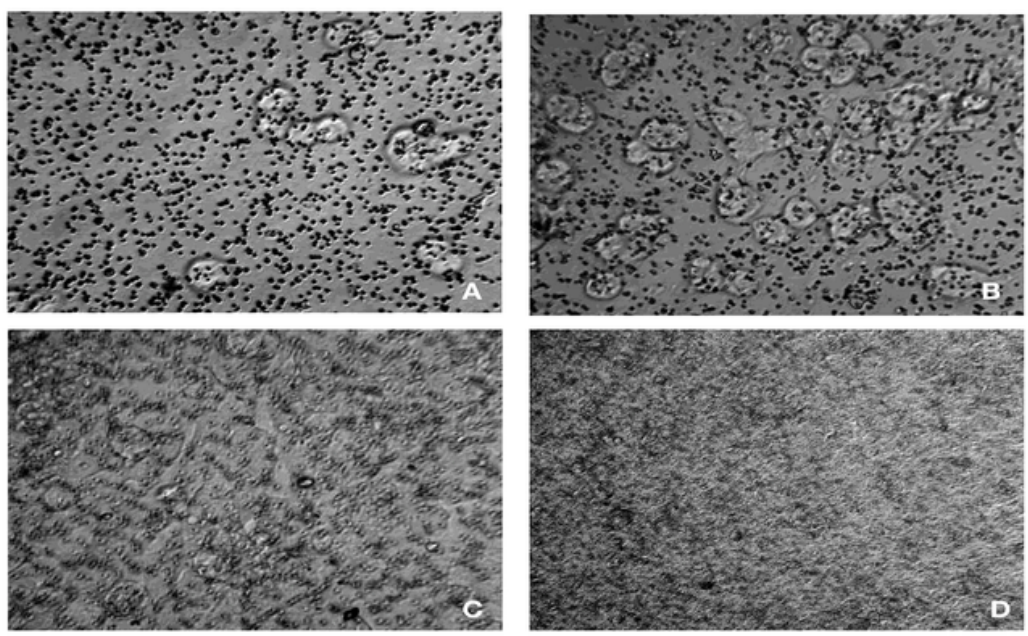

The Caco-2 cell growth morphology condition at different culture times A:0 day; B: 7 day; C:14 day D:21 day

Figure 4

AKP activity, TEER value and growth morphology condition of Caco-2 cell monolayer model at different culture times 


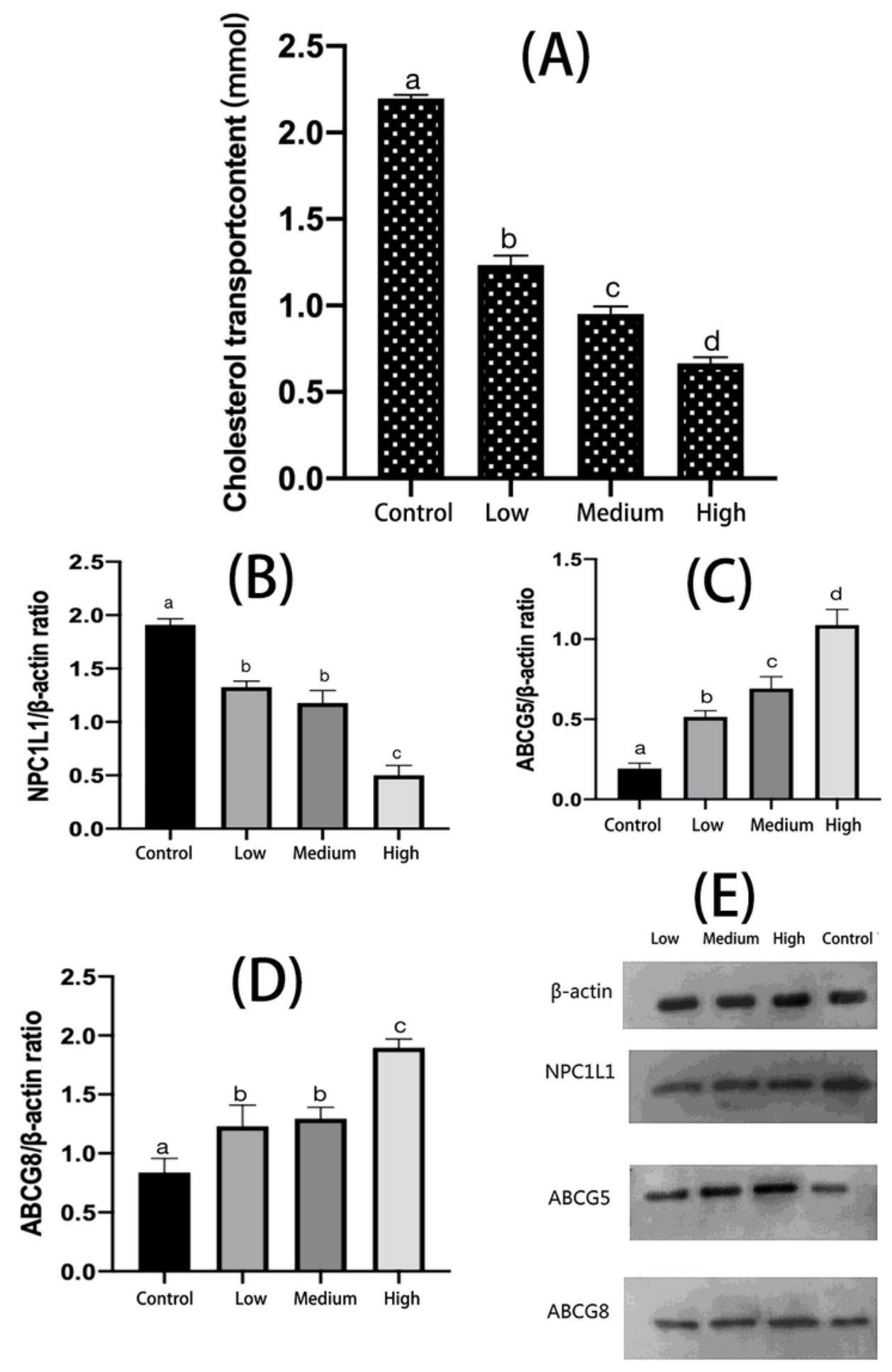

Figure 5

Effects of IPPF on cholesterol transport content $(A)$ and protein levels to cholesterol absorption [NPC1L1(B), ABCG5 (C) and ABCG8(D)] in Caco-2 cells Different letters in the figure denote significant differences $(P<0.05)$ with control. 

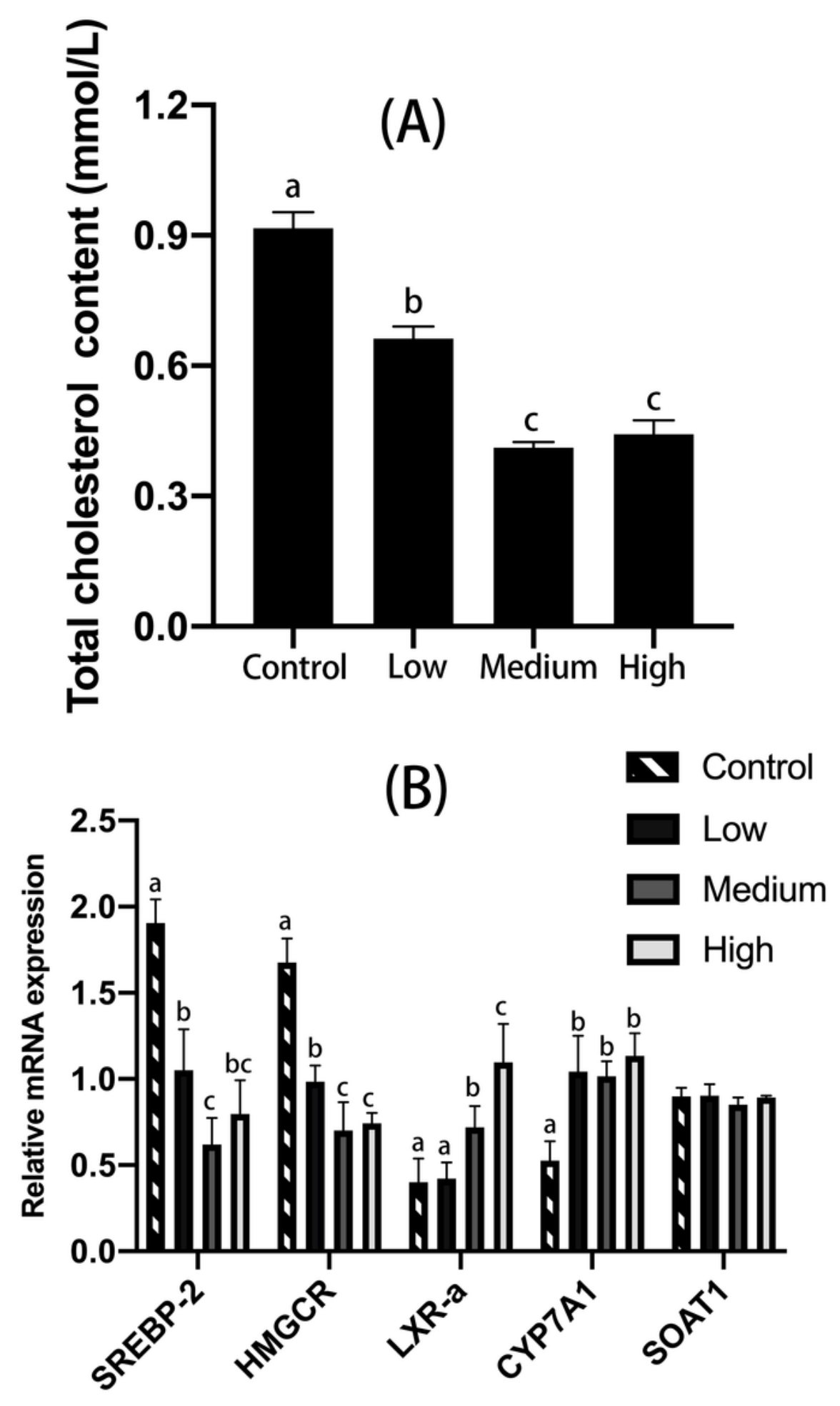

Figure 6

Effects of IPPF on the total cholesterol content (A) and mRNA levels related to cholesterol metabolism (B) in HepG2 cells Different letters in the figure denote significant differences $(P<0.05)$ with control 


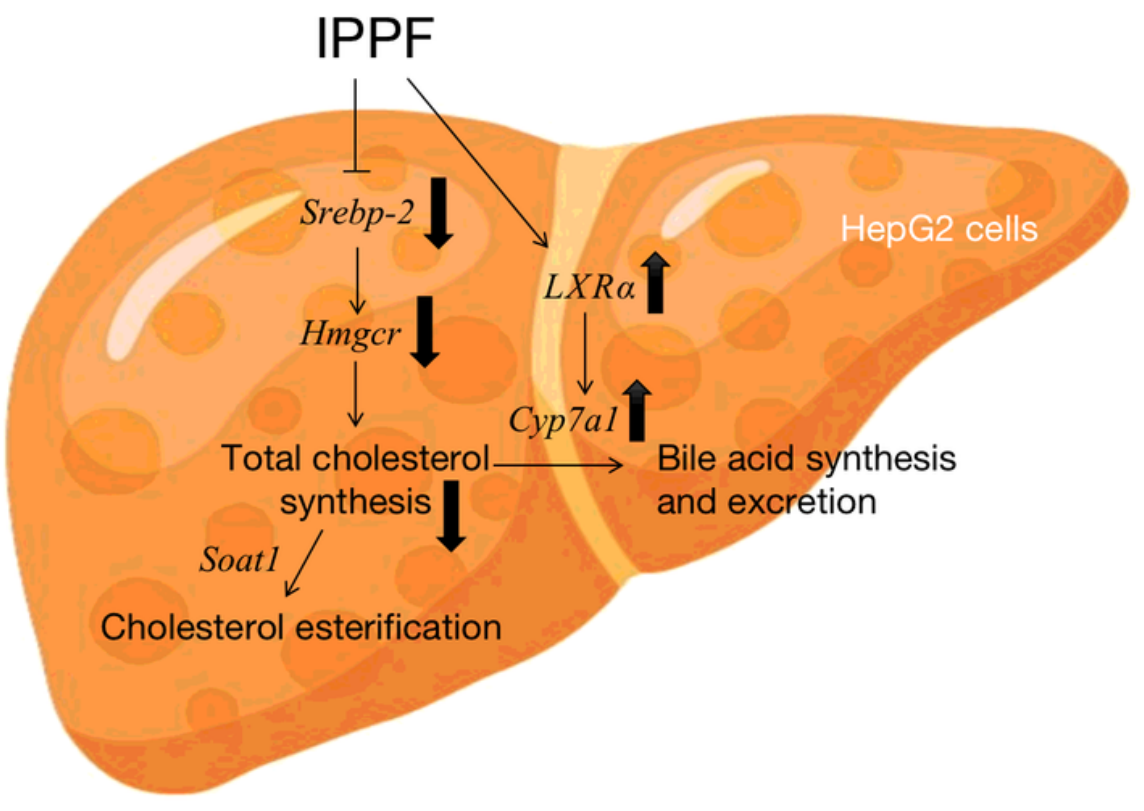

Figure 7

IPPF regulates hepatic cholesterol metabolism in HepG2 cells

\section{Supplementary Files}

This is a list of supplementary files associated with this preprint. Click to download.

- Gabstract.png 